\title{
AEDES AEGYPTI EN ZONA RURAL DEL MUNICIPIO DE LA MESA (CUNDINAMARCA) COLOMBIA, S. A.
}

\author{
ALBERTO MORALES.*
}

Es bien sabida la importancia del mosquito Aedes aegypti en la transmisión, de los cuatro tipos conocidos del virus del Dengue y del virus de la Fiebre Amarilla Urbana. El último episodio de Fiebre Amarilla Urbana en Colombia ocurrió en el año de 1929 en la población de Socorro (Santander); sin embargo, la presencia del mosquito en áreas urbanas cercanas a focos enzoóticos de Fiebre Amarilla Selvática constituye un peligro potencial. Desde el año de 1972 se vienen presentando en el país epidemias de Dengue debidas al virus tipo II, más tarde hizo su aparición el tipo III y más recientemente el tipo I, todos transmitidos por A. aegypti, el único vector conocido de Dengue en las Américas.

En Colombia, como en el resto de América en donde existe el A. aegypti, el mosquito es de hábitos domésticos y se le encuentra en áreas urbanas; en ciertas ocasiones se le puede hallar en lugares con muy pocas casas y aún en casas aisladas, pero siempre con el común denominador de que estas viviendas se encuentran en sitios conectados por vías de comunicación vehicular que facilitan el transporte ya sea de los mosquitos adultos o de los huevos y larvas del insecto.

El propósito de esta comunicación breve es el dar a conocer el encuentro de Aedes aegyptien una zona rural del municipio de la Mesa (Cundinamarca), específicamente en la vereda Santa Bárbara, mientras se realizaba una encuesta sobre Lutzomyia en un foco de Leishmaniasis Cutánea.
La vereda Santa Bárbara está situada al suroeste de la zona urbana del municipio de la Mesa, muy cerca a la población; aproximadamente a 1.000 metros de altura sobre el nivel del mar, con una temperatura media de $22^{\circ} \mathrm{C}$ y un promedio anual de lluvias de 1.000 a $2.000 \mathrm{~mm}$, de acuerdo a la clasificación de Holdridge, esta área corresponde a "bosque húmedo premontano (transición cálida)”. Es una área dedicada especialmente al cultivo del café; se encuentran además árboles de diversas especies, los cuales sirven de "sombrío" en los cafetales, matas de plátano y algunos árboles frutales.

Para llegar desde la población hasta los límites donde se inicia la vereda se emplean aproximadamente 10 minutos en un vehículo automotor. Sin embargo, dentro de la misma vereda no existe ningún carreteable y la comunicación se hace por caminos de "herradura". De acuerdo con los límites señalados por los moradores para la vereda, en octubre de 1981, había dentro de ella 25 casas de habitación; cada casa corresponde a una finca aislada. Las casas están construídas en su mayor parte con paredes de bahareque $y$ techos de zinc o teja "ETERNIT" y solo muy pocas con bloques de cemento.

El agua para el consumo humano y para usos domésticos la obtienen en algunos casos de riachuelos que nacen en la misma vereda pero, en general, la consiguen almacenando agua lluvia en albercas o en canecas metálicas.

\footnotetext{
* Bacteriólogo, M. Sc. Grupo de Entomología. Instituto Nacional de Salud. Apartado 80334. Bogotá - Colombia, S.A.
} 
En los días 21 de octubre y 9, 10 y 11 de noviembre de 1981 se hizo una búsqueda de formas inmaduras y de adultos de Aedes aegypti en 16 de las 25 casas de la vereda, con el siguiente resultado: en 4 casas se encontraron larvas y adultos y en 3 casas solamente adultos. Así, pues, el índice de infestación de casas por adultos fue del $43,75 \%$ y por larvas del $25 \%$.

Las hembras adultas fueron recolectadas cuando picaban a cebo humano o cuando se encontraban en el interior de la vivienda. Los machos, cuando estaban reposando en las paredes de las viviendas o en el momento en que trataban de copular con las hembras atraídas por cebo humano. En las 7 casas positivas a adultos se recolectó un total de 61 ๆ y 74 of

En cuanto a larvas de Aedes aegypti, se encontraron 4 casas positivas, así: en la primera había 4 canecas metálicas con larvas; en la segunda, una alberca; en la tercera se encontraron infestados un tanque de cemento y una alberca y en la cuarta, hubo dos tanques de cemento con larvas.
Es obvia la importancia que tiene el hallazgo de Aedes aegypti en viviendas de área rural, en fincas cafeteras, por las implicaciones que este hecho puede tener en los programas de control del mosquito y además por el peligro potencial que representa su presencia en estas áreas como vector de algunos arbovirus.

Será necesario hacer una búsqueda intensiva del mosquito en la totalidad de las casas de la vereda Santa Bárbara y de las veredas vecinas, para tratar de evaluar la magnitud del problema, pero ante todo, se quiere alertar a todas aquellas personas e instituciones vinculadas al estudio y control del Aedes aegypti acerca de la posibilidad del hallazgo de esta especie en condiciones similares o parecidas.

\section{AGRADECIMIENTOS}

Al señor Enrique Martínez, ayudante de la Sección de Entomología, INS y al señor Víctor Manuel Ochoa, ayudante de la Sección de Parasitología, INS, por su ayuda en el trabajo de campo. 